\title{
Evaluating the Long-Term Cost-Effectiveness of Once- Weekly Semaglutide Versus Once-Daily Liraglutide for the Treatment of Type 2 Diabetes in the UK
}

\author{
Pierre Johansen (D) · Barrie Chubb · Barnaby Hunt · Samuel J. P. Malkin • \\ Anna Sandberg · Matthew Capehorn
}

Received: February 20, 2020 / Published online: April 18, 2020

(C) The Author(s) 2020

\begin{abstract}
Introduction: Once-weekly semaglutide $1 \mathrm{mg}$ is a novel glucagon-like peptide-1 receptor agonist (GLP-1 RA) for the treatment of type 2 diabetes that has demonstrated significantly greater reductions in glycated haemoglobin (HbA1c) and body weight than the GLP-1 RA once-daily liraglutide $1.2 \mathrm{mg}$ in the SUSTAIN 10 trial. The present analysis aimed to evaluate the longterm cost-effectiveness of once-weekly semaglutide $1 \mathrm{mg}$ versus once-daily liraglutide $1.2 \mathrm{mg}$ from a UK healthcare payer perspective. Methods: Long-term outcomes were projected using the IQVIA CORE Diabetes Model (version 9.0), with baseline characteristics and treatment effects sourced from SUSTAIN 10.
\end{abstract}

Digital Features To view digital features for this article go to https://doi.org/10.6084/m9.figshare.12063384.

Electronic Supplementary Material The online version of this article (https://doi.org/10.1007/s12325020-01337-7) contains supplementary material, which is available to authorized users.

P. Johansen $(\varangle) \cdot$ B. Chubb · A. Sandberg

Novo Nordisk A/S, Søborg, Denmark

e-mail: pirj@novonordisk.com

B. Hunt · S. J. P. Malkin

Ossian Health Economics and Communications

$\mathrm{GmbH}$, Basel, Switzerland

M. Capehorn

Rotherham Institute for Obesity, Rotherham, UK
Patients were assumed to initiate treatment with GLP-1 RAs and continue treatment until HbA1c exceeded 7.5\%, at which point GLP-1 RAs were discontinued and basal insulin was initiated. Pharmacy costs and costs of complications were measured in 2018 pounds sterling (GBP), with future costs and outcomes discounted at $3.5 \%$ per annum. Utilities were taken from published sources.

Results: In the base-case analysis, once-weekly semaglutide $1 \mathrm{mg}$ was associated with an increase in discounted life expectancy of 0.21 years and discounted quality-adjusted life expectancy of 0.30 quality-adjusted life-years, compared with once-daily liraglutide $1.2 \mathrm{mg}$. Clinical benefits were achieved at reduced costs, with lifetime cost savings of GBP 140 per patient with semaglutide versus liraglutide, owing to a reduction in diabetes-related complications, in particular cardiovascular disease (mean cost saving of GBP 279 per patient). Therefore, once-weekly semaglutide $1 \mathrm{mg}$ was dominant compared with once-daily liraglutide $1.2 \mathrm{mg}$. The results of the sensitivity analyses were similar, demonstrating the robustness of the base-case analysis.

Conclusions: Once-weekly semaglutide $1 \mathrm{mg}$ is a cost-effective treatment option versus oncedaily liraglutide $1.2 \mathrm{mg}$, based on the SUSTAIN 10 trial, from a UK healthcare payer perspective. 
Keywords: Cost-effectiveness; Diabetes; Economic evaluation; Glucagon-like peptide-1 receptor agonists; Liraglutide; Semaglutide; Type 2 diabetes

\section{Key Summary Points}

Why carry out this study?

Type 2 diabetes (T2D) is associated with a significant clinical and economic burden in the UK.

Once-weekly semaglutide $1 \mathrm{mg}$, a novel glucagon-like peptide-1 receptor agonist (GLP-1 RA) treatment for T2D, has demonstrated significantly greater reductions in glycated haemoglobin and body weight than the GLP-1 RA oncedaily liraglutide $1.2 \mathrm{mg}$ in the SUSTAIN 10 trial.

The present analysis aimed to evaluate the long-term cost-effectiveness of onceweekly semaglutide $1 \mathrm{mg}$ versus oncedaily liraglutide $1.2 \mathrm{mg}$ from a UK healthcare payer perspective.

\section{What was learned from the study?}

Once-weekly semaglutide $1 \mathrm{mg}$ was dominant (more effective and less costly) compared with once-daily liraglutide 1.2 $\mathrm{mg}$.

Therefore, once-weekly semaglutide $1 \mathrm{mg}$ is a cost-effective treatment option versus once-daily liraglutide $1.2 \mathrm{mg}$, from a UK healthcare payer perspective.

\section{INTRODUCTION}

Diabetes is associated with a significant clinical and economic burden in the UK, with approximately $6 \%$ of the population affected by the disease, $90 \%$ of whom have type 2 diabetes (T2D) $[1,2]$. The prevention and treatment of diabetes, together with the management of related complications, are associated with a high financial burden; in 2017, diabetes-related healthcare expenditure exceeded 10 billion international dollars [3]. Diabetes was estimated to account for approximately $10 \%$ of the total National Health Service budget in 2010/2011 and this is expected to rise to $17 \%$ in $2035 / 2036$ [4]. Furthermore, the burden of diabetes on patients is considerable. Affected individuals have a reduced quality of life compared with the general population, owing to the comorbidities associated with diabetes and the requirement for monitoring and management [1]. The economic burden of diabetes and the impact of diabetes on patients' lives can be quantified in economic analyses using robust, well-validated models. These analyses inform healthcare decision-making by identifying the most cost-effective therapeutic options.

The National Institute for Health and Care Excellence (NICE) guidance recommends that people with T2D start therapy with metformin and then intensify pharmacological management with the addition of second and third drugs if they do not achieve adequate glycaemic control. If triple therapy with metformin and two other oral drugs is not effective, not tolerated or contraindicated, then glucagon-like peptide-1 receptor agonists (GLP-1 RAs) are recommended for patients with a body mass index (BMI) of $35 \mathrm{~kg} / \mathrm{m}^{2}$ or higher [5]. GLP-1 RAs are associated with improved glycaemic control, reductions in body weight and a low risk of hypoglycaemia [6]. In turn, improvements in glycaemic control confer a reduced risk of long-term diabetes-related complications [7-9]. NICE recommends glycaemic targets (glycated haemoglobin [HbA1c]) of below 6.5\%, below $7.0 \%$, or less stringent thresholds, depending on the individual patient requirements [5]. However, in the UK in 2016-2017, only $66.8 \%$ of patients with T2D or other types of diabetes (excluding type 1 diabetes) achieved HbA1c of $7.5 \%$ or lower [10].

Both once-weekly semaglutide $1 \mathrm{mg}$ (Ozempic $^{\circledR}$; Novo Nordisk A/S) and once-daily liraglutide (Victoza ${ }^{\circledR}$; Novo Nordisk A/S) have been granted a marketing authorization for use as an adjunct to diet and exercise in adults with insufficiently controlled T2D by the European 
Medicines Agency: once-weekly semaglutide $1 \mathrm{mg}$ in 2018 [11] and once-daily liraglutide in 2009 [12]. Both can be given as a monotherapy in patients for whom metformin is not appropriate, owing to intolerance or contraindications, or in combination with other glucoselowering drugs $[11,12]$. In the UK, liraglutide $1.2 \mathrm{mg}$ was originally recommended by NICE [13]; updated guidance published in 2015 does not specify a dose [5]. Once-weekly semaglutide $1 \mathrm{mg}$ was compared with once-daily liraglutide $1.2 \mathrm{mg}$ in the SUSTAIN 10 trial (a 30-week, phase $3 \mathrm{~b}$, open-label, randomized clinical trial) and was shown to be associated with significantly greater reductions in HbA1c and body weight [14].

One of the limitations of clinical trials in diabetes is that they have a relatively short duration of follow-up and therefore many of the clinical benefits that arise from reductions in HbA1c and body weight occur after the trial has ended. To evaluate the long-term clinical and economic value of new treatments, economic modelling is widely recommended. This approach enables results from clinical trials to be extrapolated over a patient's lifetime and the cost-effectiveness of new treatments to be evaluated [15]. The aim of the present analysis was to assess the long-term cost-effectiveness of once-weekly semaglutide $1 \mathrm{mg}$ versus oncedaily liraglutide $1.2 \mathrm{mg}$ for the treatment of people with T2D who are not achieving glycaemic control with oral antidiabetic drugs, based on SUSTAIN 10 clinical trial data and from the perspective of a UK healthcare payer.

\section{METHODS}

\section{Model Overview}

Analyses were performed using the IQVIA CORE Diabetes Model (CDM; version 9.0), a mathematical model constructed to assess the costeffectiveness of interventions for diabetes, which is widely used [16-20] and accepted by health technology agencies, including NICE and the Scottish Medicines Consortium. The IQVIA CDM was originally developed in 2004 and its predictive ability was validated against epidemiological and clinical studies [21, 22]. It has since undergone a number of updates, with the most recent validation published in 2014 [23]. Further information on the model can be found on the Mount Hood Diabetes Challenge Network [24].

The IQVIA CDM is based on a series of 16 interdependent sub-models that simulate nonspecific mortality and the complications of diabetes (Fig. S1 in the supplementary material). Each sub-model has a semi-Markov structure and uses time, state, time-in-state and diabetes type-dependent probabilities derived from published sources. The model outputs include life expectancy (measured in years), quality-adjusted life expectancy (measured in quality-adjusted life-years [QALYs]), cumulative incidence and time to onset of diabetes-related complications, and direct medical costs.

\section{Overview of Model Settings}

As recommended by NICE, a lifetime (50-year) time horizon was used to capture all relevant long-term complications and associated costs, and to assess their impact on life expectancy and quality of life [25]. Clinical and cost outcomes were discounted at 3.5\% per year, consistent with the NICE reference case [25]. Risk equations from the UK Prospective Diabetes Study (UKPDS) 68 were used in the base-case analysis to predict the incidence of first microvascular and macrovascular events [26], with a number of other sources used to inform event-specific mortality (as described by Palmer et al. [21]). UK-specific life tables from the World Health Organization (data from 2016) were used to model all-cause mortality [27].

Base-case and sensitivity analyses modelled patient heterogeneity by sampling baseline characteristics from distributions parameterized on the basis of standard deviations. First-order uncertainty (variability in outcomes between identical patients) and second-order uncertainty (uncertainty in the estimation of parameters) were captured in the model using a second-order Monte Carlo approach that sampled baseline characteristics, treatment effects, costs of complications, utilities and transition 
Table 1 Treatment effects from SUSTAIN 10

\begin{tabular}{|c|c|c|}
\hline Parameter & $\begin{array}{l}\text { Once-weekly semaglutide } \\
1 \mathrm{mg}\end{array}$ & Once-daily liraglutide $1.2 \mathrm{mg}$ \\
\hline \multicolumn{3}{|l|}{ Physiological parameters, mean (standard error) } \\
\hline HbAlc, \% & $-1.72(0.05)^{\mathrm{a}}$ & $-1.03(0.05)$ \\
\hline Systolic blood pressure, $\mathrm{mmHg}$ & $-4.49(0.73)$ & $-3.50(0.73)$ \\
\hline Diastolic blood pressure, $\mathrm{mmHg}$ & $-1.74(0.47)$ & $-1.01(0.47)$ \\
\hline Total cholesterol, mg/dL & $-8.29(1.74)^{\mathrm{a}}$ & $-2.50(1.73)$ \\
\hline HDL cholesterol, $\mathrm{mg} / \mathrm{dL}$ & $+0.51(0.40)$ & $-0.49(0.38)$ \\
\hline LDL cholesterol, mg/dL & $-2.86(1.42)$ & $+0.62(1.44)$ \\
\hline Triglycerides, mg/dL & $-36.42(4.93)^{\mathrm{a}}$ & $-15.49(5.03)$ \\
\hline $\mathrm{BMI}, \mathrm{kg} / \mathrm{m}^{2}$ & $-2.03(0.09)^{\mathrm{a}}$ & $-0.68(0.09)$ \\
\hline Estimated glomerular filtration rate, $\mathrm{mL} / \mathrm{min} / 1.73 \mathrm{~m}^{2}$ & $-1.12(0.44)$ & $-0.54(0.44)$ \\
\hline \multicolumn{3}{|l|}{ Rate of hypoglycaemic events per 100 patient-years } \\
\hline Non-severe hypoglycaemia & 4.40 & 4.40 \\
\hline Severe hypoglycaemia ${ }^{\mathrm{b}}$ & 0.00 & 0.00 \\
\hline Proportion of non-severe events that are nocturnal & 0.00 & 0.00 \\
\hline Proportion of severe events that are nocturnal & 0.00 & 0.00 \\
\hline
\end{tabular}

Lipid values are presented in $\mathrm{mg} / \mathrm{dL}$, because these are required by the IQVIA CORE Diabetes Model. Total cholesterol, HDL cholesterol and LDL cholesterol values can be converted from $\mathrm{mg} / \mathrm{dL}$ to mmol/L by multiplying by 38.67 . Triglyceride values can be converted from $\mathrm{mg} / \mathrm{dL}$ to $\mathrm{mmol} / \mathrm{L}$ by multiplying by 88.5

$B M I$ body mass index, HbAlc glycated haemoglobin, $H D L$ high-density lipoprotein, $L D L$ low-density lipoprotein

a Statistically significant difference at $95 \%$ confidence level

b Defined as an event requiring assistance of another person to actively administer carbohydrates, glucagon, or take other corrective actions

probabilities relating to myocardial infarction, stroke, congestive heart failure and angina. In total, 1000 patients were each run through the simulation 1000 times.

\section{Baseline Cohort Characteristics, Treatment Effects and Hypoglycaemic Events}

Baseline clinical data were taken from the SUSTAIN 10 trial (Table S1 in the supplementary material) [14]. The mean [standard deviation (SD)] age of the cohort was 59.5 (10.2) years, with a mean duration of T2D of 9.3 (5.9) years, mean $\mathrm{HbA} 1 \mathrm{c}$ of $8.2 \%$ (1.0) and mean BMI of $33.7(6.8) \mathrm{kg} / \mathrm{m}^{2}$. For inclusion in
SUSTAIN 10, patients were required to be on stable daily doses of metformin, sulfonylurea or sodium-glucose cotransporter 2 inhibitors (SGLT2is). Treatment effects for once-weekly semaglutide $1 \mathrm{mg}$ and once-daily liraglutide $1.2 \mathrm{mg}$ were based on the 30-week data from SUSTAIN 10 and applied in the first year of the analysis (Table 1).

After the first year of treatment with onceweekly semaglutide $1 \mathrm{mg}$ or once-daily liraglutide $1.2 \mathrm{mg}$, the patient's HbA1c was assumed to increase, based on the UKPDS progression equation [26]. When HbA1c exceeded 7.5\% (the NICE threshold for treatment intensification [5]), it was assumed that the patient would discontinue treatment with once-weekly 
semaglutide $1 \mathrm{mg}$ or once-daily liraglutide $1.2 \mathrm{mg}$ and initiate treatment with basal insulin (treatment with metformin, sulfonylureas and/ or SGLT2is was continued). This treatment approach was chosen to reflect common clinical practice, whereby, owing to the progressive nature of T2D, glycaemic control cannot be maintained indefinitely with one medication [28]. This approach is widely used, including in analyses conducted by NICE [29]. The initial effect of basal insulin on HbA1c was based on data derived from an insulin-naïve population by Willis et al. [30]. The UKPDS progression equation was then used to model HbA1c for the remainder of the patients' lifetimes.

The difference in BMI between the two treatment arms was assumed to persist while patients received once-weekly semaglutide $1 \mathrm{mg}$ or once-daily liraglutide $1.2 \mathrm{mg}$, and to revert to baseline following treatment intensification to basal insulin therapy in both arms. All other treatment effects were assumed to follow the natural progression algorithms built into the CDM, based on the UKPDS or Framingham data (as described by Palmer et al. [21]).

The rates of hypoglycaemic events reported in the once-weekly semaglutide $1 \mathrm{mg}$ and oncedaily liraglutide $1.2 \mathrm{mg}$ arms were taken from the SUSTAIN 10 trial and applied for the duration of each respective treatment. Rates of hypoglycaemia following initiation of basal insulin were based on a UK study of people with T2D receiving basal insulin [31].

\section{Costs and Utilities}

Costs were estimated from a UK healthcare payer perspective and expressed in 2018 pounds sterling (GBP). Costs were inflated using the hospital and community health services index provided by the Personal Social Services Research Unit (PSSRU) when necessary [32]. Pharmacy costs were taken from the Monthly Index of Medical Specialities (MIMS) database in October 2019; the pack cost for 28 days of once-weekly semaglutide $1 \mathrm{mg}$ was GBP 73.25 and the cost for 30 days of once-daily liraglutide $1.2 \mathrm{mg}$ was GBP 78.48. Other pharmacy costs are given in Table $\mathrm{S} 2$ and annual treatment costs are given in Table S3 in the supplementary material.

Costs associated with the treatment of diabetes-related complications were identified through a literature review conducted in 2017 and, when necessary, updated or inflated to the most recent costs available (2018 GBP) using the healthcare inflation index published by the PSSRU [32], or by taking data from the most recent version of the published source (Table S4 in the supplementary material).

Utilities associated with diabetes and diabetes-related complications were taken from a review by Beaudet et al. 2014 [33] and hypoglycaemic event disutilities were taken from Evans et al. 2013 [34], published after the literature searches conducted by Beaudet et al. had been conducted (Table S5 in the supplementary material). Whenever possible, Beaudet et al. selected values from the literature elicited using the 5-dimension EuroQol questionnaire (EQ5D), in line with the NICE reference case [33].

\section{Sensitivity Analyses}

In total, 16 sensitivity analyses were run to test the robustness of the assumptions and inputs used in the base-case analysis, as detailed in the Supplementary Methods. These included a deterministic analysis of the base case (i.e. no sampling of patient characteristics, treatment effects, costs of complications or transition probabilities), for replicability purposes.

\section{Compliance with Ethics Guidelines}

This article is based on previously conducted studies and does not contain any studies with human participants or animals performed by any of the authors.

\section{RESULTS}

\section{Base-Case Analysis}

Differences in simulated treatment effects led to differences in projected long-term clinical outcomes between once-weekly semaglutide $1 \mathrm{mg}$ 
and once-daily liraglutide $1.2 \mathrm{mg}$, including the time to onset of diabetes-related complications (Fig. S2 in the supplementary material), mortality (simulated survival shown in Fig. S3 in the supplementary material) and the time it took for patients to require treatment intensification. Simulated HbA1c and BMI at the population level are shown in Figs. 1 and 2, respectively, which show change over time to be a smooth curve. The reason for this is that populationlevel graphs use the average of all simulated patients run through the model. Because baseline characteristics and treatment effects were sampled on the basis of the standard deviations, these differed among simulated patients and led to differences in the time at which treatment intensification occurred. The deterministic sensitivity analysis does not include sampling of patient baseline characteristics or treatment effects and the graphs showing HbA1c and BMI in this analysis are not smooth curves (Figs. S4 and S5).

Once-weekly semaglutide $1 \mathrm{mg}$ was associated with an improvement in undiscounted life expectancy of 0.40 years and a gain in undiscounted quality-adjusted life expectancy of 0.42 QALYs compared with once-daily liraglutide $1.2 \mathrm{mg}$. With once-weekly semaglutide $1 \mathrm{mg}$, discounted life expectancy increased by 0.21 years $(95 \%$ confidence interval [CI] $0.19-0.22$ ) and discounted quality-adjusted life expectancy increased by 0.30 QALYs (95\% CI

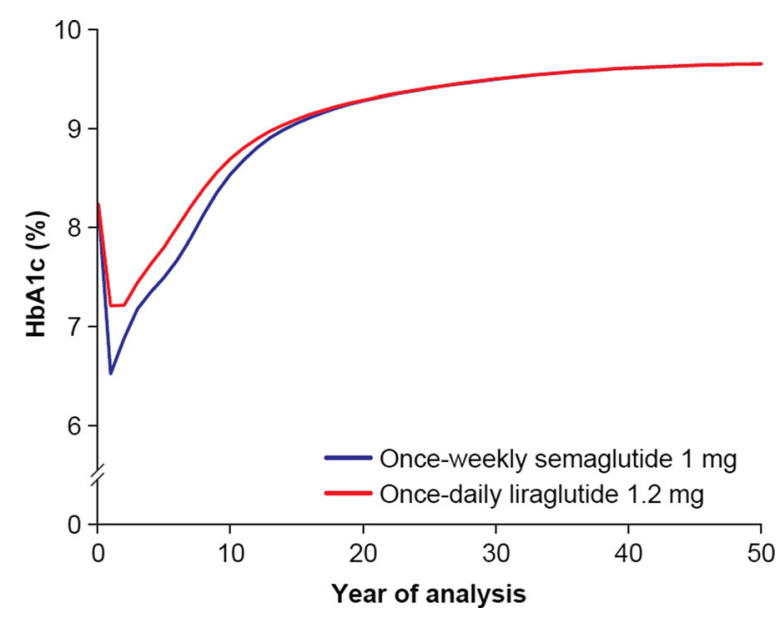

Fig. 1 Population-level HbAlc progression curves. HbA1c glycated haemoglobin

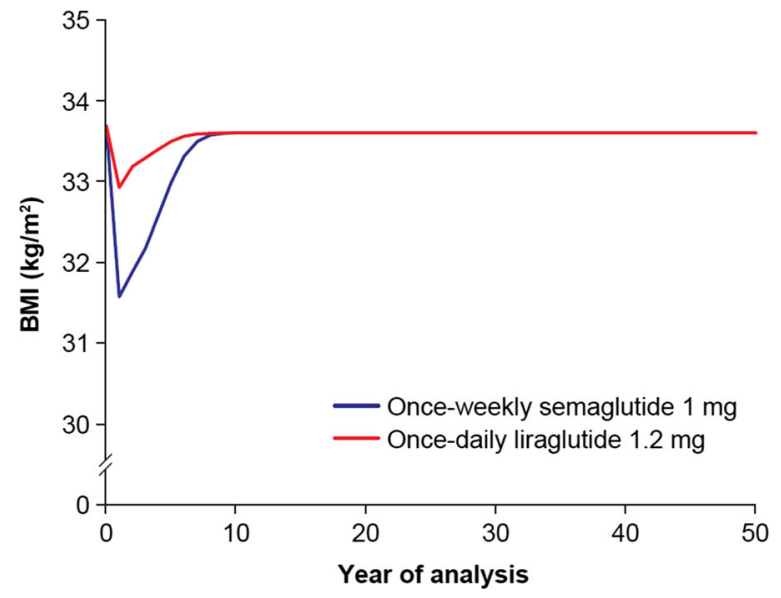

Fig. 2 Population-level BMI progression curves. BMI body mass index

$0.29-0.31)$, compared with once-daily liraglutide $1.2 \mathrm{mg}$ (Table 2).

Once-weekly semaglutide $1 \mathrm{mg}$ was associated with cost savings of GBP 140 per patient compared with once-daily liraglutide $1.2 \mathrm{mg}$. The cost of treatment with once-weekly semaglutide $1 \mathrm{mg}$ was higher than with oncedaily liraglutide $1.2 \mathrm{mg}$ because the duration of treatment was longer. However, the increased treatment cost was offset by cost savings owing to greater avoidance of diabetes-related complications, most notably cardiovascular disease (mean cost saving of GBP 279 per patient; Fig. 3). In addition, the mean time to the onset of complications was longer with once-weekly semaglutide $1 \mathrm{mg}$ than with once-daily liraglutide $1.2 \mathrm{mg}$ (Fig. S2 in the supplementary material). With improved clinical benefits and cost savings, once-weekly semaglutide $1 \mathrm{mg}$ was considered dominant over once-daily liraglutide $1.2 \mathrm{mg}$.

The effect of including parameter uncertainty on the difference in QALYs and costs between once-weekly semaglutide $1 \mathrm{mg}$ and once-daily liraglutide $1.2 \mathrm{mg}$ is shown in the scatter plot in Fig. 4 . The probability of onceweekly semaglutide $1 \mathrm{mg}$ being considered costeffective at a willingness-to-pay threshold of GBP 20,000 per QALY gained was 99.2\% (Fig. S6 in the supplementary material). 
Table 2 Long-term cost-effectiveness outcomes

\begin{tabular}{|c|c|c|c|}
\hline Health outcomes & $\begin{array}{l}\text { Once-weekly } \\
\text { semaglutide } 1 \mathrm{mg}\end{array}$ & $\begin{array}{l}\text { Once-daily liraglutide } \\
1.2 \mathrm{mg}\end{array}$ & Difference $(95 \% \mathrm{CI})$ \\
\hline Discounted life expectancy, years & $12.48(2.94)$ & $12.27(2.95)$ & $\begin{array}{l}+0.21(+0.19 \\
\text { to }+0.22)\end{array}$ \\
\hline $\begin{array}{l}\text { Discounted quality-adjusted life } \\
\text { expectancy, QALYs }\end{array}$ & $6.58(1.49)$ & $6.28(1.48)$ & $\begin{array}{l}+0.30(+0.29 \\
\text { to }+0.31)\end{array}$ \\
\hline Discounted direct costs, GBP & $25,972(6091)$ & $26,112(6149)$ & $\begin{array}{l}-140(-198 \\
\text { to }-83)\end{array}$ \\
\hline ICER, GBP per QALY gained & Semaglutide dominant & & \\
\hline
\end{tabular}

Values are means (standard deviation) unless otherwise stated

CI confidence interval, GBP 2018 pounds sterling, ICER incremental cost-effectiveness ratio, QALY quality-adjusted lifeyear

\section{Sensitivity Analyses}

The sensitivity analyses showed that the basecase results were robust to changes in the input parameters and assumptions used (Table 3). Once-weekly semaglutide $1 \mathrm{mg}$ was dominant compared with once-daily liraglutide $1.2 \mathrm{mg}$ in all sensitivity analyses except the deterministic analysis. In this analysis, costs were higher with once-weekly semaglutide $1 \mathrm{mg}$ than with oncedaily liraglutide $1.2 \mathrm{mg}$ (cost difference, GBP 142) and the incremental cost-effectiveness ratio was GBP 315 per QALY gained for onceweekly semaglutide $1 \mathrm{mg}$.

\section{DISCUSSION}

Once-weekly semaglutide $1 \mathrm{mg}$ was dominant compared with once-daily liraglutide $1.2 \mathrm{mg}$ on the basis of data from the SUSTAIN 10 trial, with an increase in discounted quality-adjusted life-expectancy of 0.30 QALYs and a reduction in direct costs of GBP 140 per patient in people with T2D. Although cost savings were small at a patient level, they translate to a large saving at a population level.

Improvements in glycaemic control were greater with once-weekly semaglutide $1 \mathrm{mg}$ than with once-daily liraglutide $1.2 \mathrm{mg}$, resulting in a longer time to treatment intensification with basal insulin and, consequently, higher treatment costs. However, this was offset by the greater avoidance of diabetes-related complications with once-weekly semaglutide $1 \mathrm{mg}$ than with once-daily liraglutide $1.2 \mathrm{mg}$, and therefore overall direct costs were lower with semaglutide. In addition, the cost of onceweekly semaglutide $1 \mathrm{mg}$ was offset by a reduction in insulin costs, compared with oncedaily liraglutide $1.2 \mathrm{mg}$, because patients receiving semaglutide initiated basal insulin later. These findings are consistent with similar analyses from Denmark and Estonia based on a network meta-analysis that compared onceweekly semaglutide $1 \mathrm{mg}$ with once-daily liraglutide $1.2 \mathrm{mg}[18,35]$.

Use of short-term data to project long-term outcomes is one of the essential tenets of health economics modelling and is agreed to be the best option available to inform decision-making when long-term clinical trial data are not available. Indeed, NICE recommends that outcomes should be modelled over patient lifetimes, in the absence of long-term data [25]. To minimize the uncertainty that can arise from this type of modelling, a diabetes model that has been extensively published and validated against real-life data was used, and extensive sensitivity analyses were performed to test the robustness of the base-case findings $[22,23]$.

Our modelling approaches for HbA1c progression and treatment intensification were clinically relevant and in line with recent 


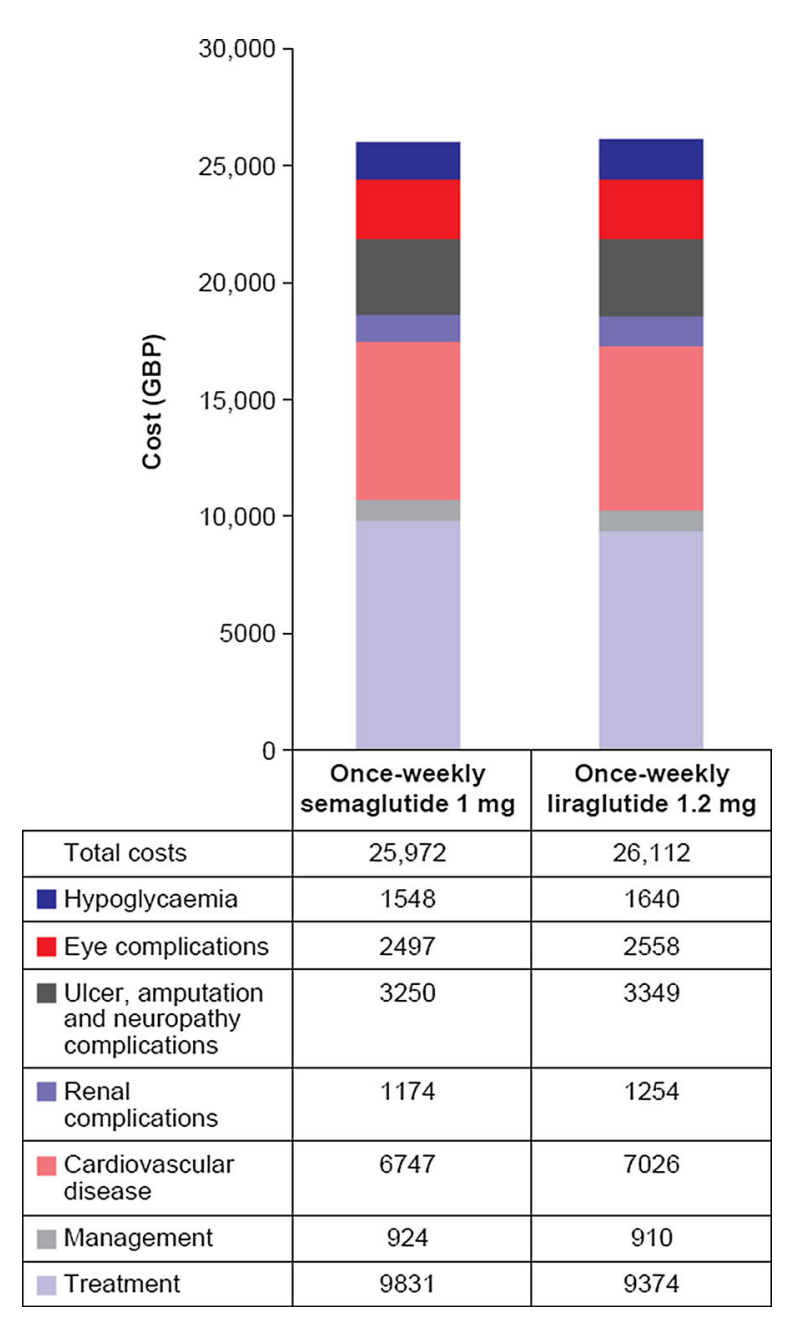

Fig. 3 Mean direct cost over a patient's lifetime. GBP 2018 pounds sterling

published cost-effectiveness evaluations of SGLT2is and GLP-1 RAs [16, 18, 36, 37], and an evaluation of SGLT2is conducted by NICE as part of a multiple technology appraisal [29]. The treatment approach was chosen to reflect clinical practice, whereby patients with T2D continue treatment while they maintain glycaemic control, and treatment is intensified as the disease progresses and glycaemic control worsens. Our assumed threshold for treatment intensification (HbA1c greater than 7.5\%) was based on NICE guidelines and the multiple technology appraisal of SGLT2is conducted by NICE, mentioned above [29]. Change in HbA1c following initiation of basal insulin was based on multivariate equations that were informed by a variety of sources [30]. However, we acknowledge that few patients in these sources had received GLP-1 RAs before initiating basal insulin and therefore changes in HbA1c in our population following discontinuation of GLP-1 RAs and initiation of basal insulin may differ from those calculated. In addition, not all patients discontinue treatment with GLP-1 RAs before initiating treatment with basal insulin in clinical practice. However, because the overall treatment duration with once-weekly semaglutide $1 \mathrm{mg}$ and once-daily liraglutide $1.2 \mathrm{mg}$ would be the same, the treatment costs for continuing once-weekly semaglutide $1 \mathrm{mg}$ and once-daily liraglutide $1.2 \mathrm{mg}$ would be very similar. Consequently, we expect that our results would be even more favourable for onceweekly semaglutide $1 \mathrm{mg}$ versus once-daily liraglutide $1.2 \mathrm{mg}$ under this assumption, compared with the base case analysis.

One limitation of the analysis was that the UKPDS risk equations used to model HbA1c progression after the first year of treatment with once-weekly semaglutide $1 \mathrm{mg}$ or once-daily liraglutide $1.2 \mathrm{mg}$ are based on data published 20 years ago [26]. They may, therefore, no longer be as applicable in modern clinical practice. However, there are no readily available, long-term studies in people with T2D that have a similar duration of follow-up to the data that we used.

A further limitation of this analysis is that we were unable to include data from the cardiovascular outcomes trials (CVOTs) evaluating once-weekly semaglutide $0.5 \mathrm{mg}$ or $1 \mathrm{mg}$ (SUSTAIN 6) [38] and once-daily liraglutide $1.8 \mathrm{mg}$ (LEADER) [39] versus placebo plus standard of care. This is because the results of CVOTs have not been integrated into risk equations for projecting outcomes in patients with T2D. Both SUSTAIN 6 and LEADER showed a reduction in the risk of experiencing a major cardiovascular event with once-weekly semaglutide $0.5 \mathrm{mg}$ and $1 \mathrm{mg}$, and once-daily liraglutide $1.8 \mathrm{mg}$, respectively, compared with placebo [38, 39]. Early analyses suggest that incorporation of the impact of treatments on cardiovascular risk can have a substantial effect on projected outcomes [40]. However, because CVOTs are generally conducted in patients at 


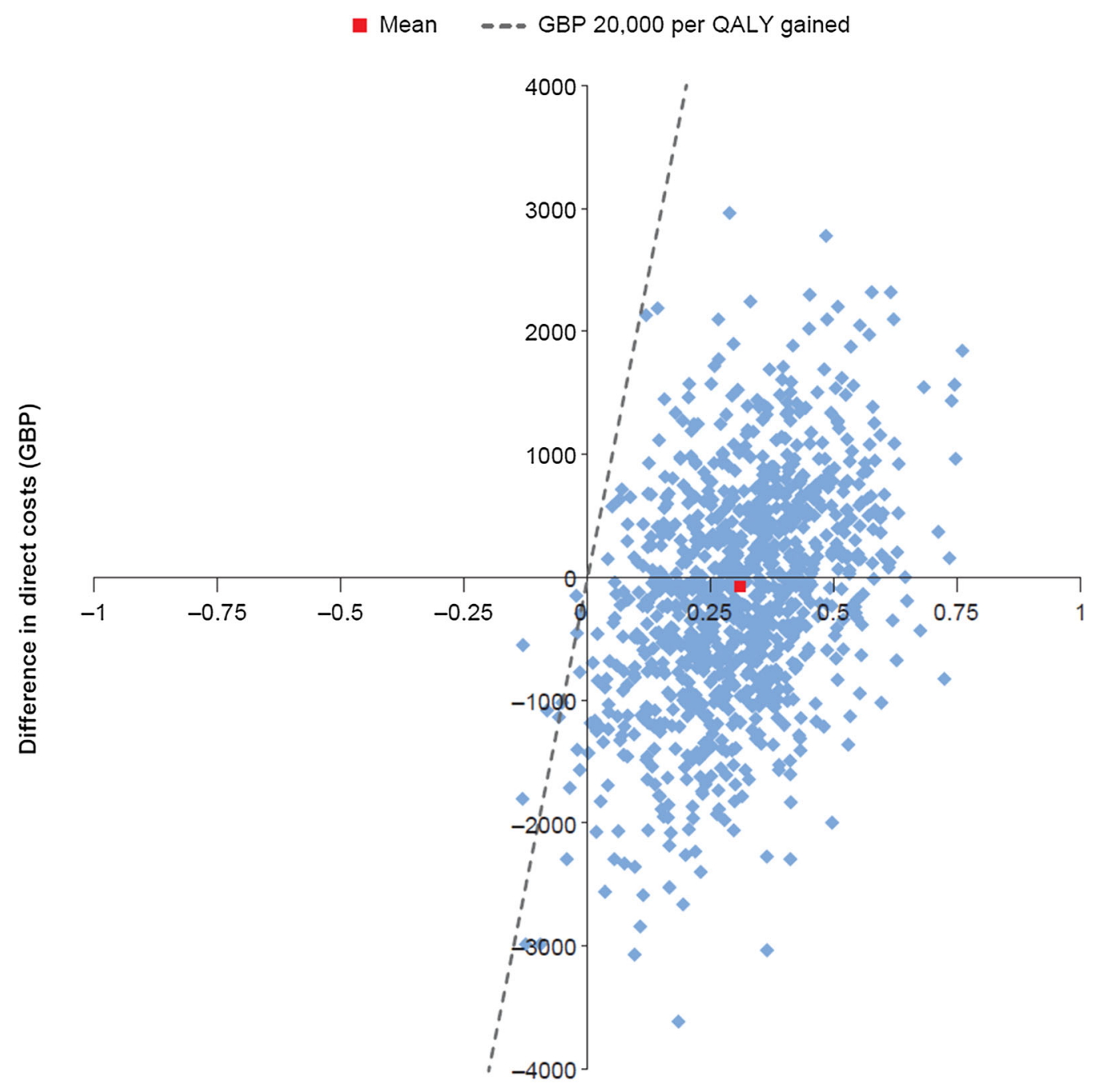

Difference in quality-adjusted life expectancy (QALYs)

Fig. 4 Probabilistic sensitivity analyses scatter plot. GBP 2018 pounds sterling, QALY quality-adjusted life-year

high risk for cardiovascular disease, it is unclear how the risk of events in the general population with T2D, such as those enrolled in SUSTAIN 10, would be affected by once-weekly semaglutide $0.5 \mathrm{mg}$ or $1 \mathrm{mg}$, or once-daily liraglutide $1.8 \mathrm{mg}$. Furthermore, it is challenging to separate the direct impact of GLP-1 RAs on cardiovascular risk from the indirect impact on risk via improved glycaemic control. An additional consideration is that patients in CVOTs receiving placebo plus standard of care were allowed to switch treatments within the standard of care regimen, which may affect the results of these studies, and limit their usefulness in our analyses.

\section{CONCLUSION}

The results of this analysis suggest that onceweekly semaglutide $1 \mathrm{mg}$ is dominant (more effective and less costly) compared with oncedaily liraglutide $1.2 \mathrm{mg}$, from a UK healthcare payer perspective. 
Table 3 Results of the sensitivity analyses

\begin{tabular}{|c|c|c|c|c|c|c|c|}
\hline \multirow[t]{2}{*}{ Analysis } & \multicolumn{3}{|c|}{$\begin{array}{l}\text { Discounted quality-adjusted life } \\
\text { expectancy, QALYs }\end{array}$} & \multicolumn{3}{|c|}{ Discounted direct costs, GBP } & \multirow{2}{*}{$\begin{array}{l}\text { ICER, GBP } \\
\text { per QALY } \\
\text { gained }\end{array}$} \\
\hline & $\begin{array}{l}\text { Once- } \\
\text { weekly } \\
\text { semaglutide } \\
1 \mathrm{mg}\end{array}$ & $\begin{array}{l}\text { Once-daily } \\
\text { liraglutide } \\
1.2 \mathrm{mg}\end{array}$ & $\overline{\text { Difference }}$ & $\begin{array}{l}\text { Once- } \\
\text { weekly } \\
\text { semaglutide } \\
1 \mathrm{mg}\end{array}$ & $\begin{array}{l}\text { Once-daily } \\
\text { liraglutide } \\
1.2 \mathrm{mg}\end{array}$ & $\overline{\text { Difference }}$ & \\
\hline Base case & 6.58 & 6.28 & +0.30 & 25,972 & 26,112 & -140 & $\begin{array}{r}\text { Semaglutide } \\
\text { dominant }\end{array}$ \\
\hline 20-year time horizon & 5.90 & 5.64 & +0.26 & 19,757 & 19,997 & -240 & $\begin{array}{r}\text { Semaglutide } \\
\text { dominant }\end{array}$ \\
\hline 10-year time horizon & 4.30 & 4.08 & +0.21 & 11,840 & 11,898 & -58 & $\begin{array}{r}\text { Semaglutide } \\
\text { dominant }\end{array}$ \\
\hline $0 \%$ discount rates & 9.48 & 9.06 & +0.42 & 44,474 & 44,557 & -83 & $\begin{array}{r}\text { Semaglutide } \\
\text { dominant }\end{array}$ \\
\hline $\begin{array}{l}\text { Only significantly } \\
\text { different treatment } \\
\text { effects included }\end{array}$ & 6.57 & 6.28 & +0.28 & 26,008 & 26,112 & -104 & $\begin{array}{r}\text { Semaglutide } \\
\text { dominant }\end{array}$ \\
\hline $\begin{array}{l}\text { Disutility for } \\
\text { BMI }>25 \mathrm{~kg} / \mathrm{m}^{2} \\
\text { taken from Lee } \\
\text { et al. } 2005[41] \\
(-0.01)\end{array}$ & 6.16 & 5.85 & +0.31 & 25,972 & 26,112 & -140 & $\begin{array}{r}\text { Semaglutide } \\
\text { dominant }\end{array}$ \\
\hline $\begin{array}{l}\text { Disutilities for } \\
\text { hypoglycaemic } \\
\text { events from Currie } \\
\text { et al. } 2006[42] \\
\text { (non-severe, } \\
-0.0118 \text {; severe, } \\
-0.0035 \text { ) }\end{array}$ & 7.31 & 7.05 & +0.26 & 25,972 & 26,112 & -140 & $\begin{array}{r}\text { Semaglutide } \\
\text { dominant }\end{array}$ \\
\hline $\begin{array}{l}\text { UKPDS } 82 \text { risk } \\
\text { equations }\end{array}$ & 6.82 & 6.58 & +0.24 & 26,444 & 26,626 & -182 & $\begin{array}{r}\text { Semaglutide } \\
\text { dominant }\end{array}$ \\
\hline $\begin{array}{l}\text { HbAlc progression } \\
\text { based on the } \\
\text { metformin arm of } \\
\text { the ADOPT study } \\
\text { [43] }(0.14 \% \text { per } \\
\text { year })\end{array}$ & 7.32 & 6.65 & +0.66 & 26,343 & 26,423 & -80 & $\begin{array}{r}\text { Semaglutide } \\
\text { dominant }\end{array}$ \\
\hline
\end{tabular}


Table 3 continued

\begin{tabular}{|c|c|c|c|c|c|c|c|}
\hline \multirow[t]{2}{*}{ Analysis } & \multicolumn{3}{|c|}{$\begin{array}{l}\text { Discounted quality-adjusted life } \\
\text { expectancy, QALYs }\end{array}$} & \multicolumn{3}{|c|}{ Discounted direct costs, GBP } & \multirow{2}{*}{$\begin{array}{l}\text { ICER, GBP } \\
\text { per QALY } \\
\text { gained }\end{array}$} \\
\hline & $\begin{array}{l}\text { Once- } \\
\text { weekly } \\
\text { semaglutide } \\
1 \mathrm{mg}\end{array}$ & $\begin{array}{l}\text { Once-daily } \\
\text { liraglutide } \\
1.2 \mathrm{mg}\end{array}$ & $\overline{\text { Difference }}$ & $\begin{array}{l}\text { Once- } \\
\text { weekly } \\
\text { semaglutide } \\
1 \mathrm{mg}\end{array}$ & $\begin{array}{l}\text { Once-daily } \\
\text { liraglutide } \\
1.2 \mathrm{mg}\end{array}$ & $\overline{\text { Difference }}$ & \\
\hline $\begin{array}{l}\text { Lipids returned to } \\
\text { baseline following } \\
\text { basal insulin } \\
\text { initiation and no } \\
\text { further progression } \\
\text { occurred }\end{array}$ & 6.57 & 6.29 & +0.29 & 25,957 & 26,103 & -146 & $\begin{array}{r}\text { Semaglutide } \\
\text { dominant }\end{array}$ \\
\hline $\begin{array}{l}\text { BMI returned to } \\
\text { baseline following } \\
\text { treatment } \\
\text { intensification and } \\
\text { increased further } \\
\text { based on the Willis } \\
\text { et al. } 2017 \\
\text { equations [30] }\end{array}$ & 6.50 & 6.20 & +0.30 & 25,960 & 26,108 & -148 & $\begin{array}{r}\text { Semaglutide } \\
\text { dominant }\end{array}$ \\
\hline $\begin{array}{l}\text { Second intensification } \\
\text { to basal bolus when } \\
\text { HbAlc exceeded } \\
7.5 \% \text { during basal } \\
\text { insulin treatment }\end{array}$ & 5.59 & 5.20 & +0.40 & 32,153 & 32,954 & -801 & $\begin{array}{r}\text { Semaglutide } \\
\text { dominant }\end{array}$ \\
\hline $\begin{array}{l}\text { Treatment } \\
\text { intensification } \\
\text { occurred after } \\
3 \text { years in both } \\
\text { arms (no difference } \\
\text { in HbAlc between } \\
\text { arms after } \\
\text { treatment } \\
\text { intensification) }\end{array}$ & 6.82 & 6.69 & +0.14 & 23,772 & 24,062 & -291 & $\begin{array}{r}\text { Semaglutide } \\
\text { dominant }\end{array}$ \\
\hline $\begin{array}{l}\text { Treatment was } \\
\text { intensified with } \\
\text { insulin Semglee }{ }^{\circledR} \\
\text { (Mylan S.A.S.) }\end{array}$ & 6.58 & 6.28 & +0.30 & 25,464 & 25,574 & -110 & $\begin{array}{r}\text { Semaglutide } \\
\text { dominant }\end{array}$ \\
\hline
\end{tabular}


Table 3 continued

\begin{tabular}{|c|c|c|c|c|c|c|c|}
\hline \multirow[t]{2}{*}{ Analysis } & \multicolumn{3}{|c|}{$\begin{array}{l}\text { Discounted quality-adjusted life } \\
\text { expectancy, QALYs }\end{array}$} & \multicolumn{3}{|c|}{ Discounted direct costs, GBP } & \multirow{2}{*}{$\begin{array}{l}\text { ICER, GBP } \\
\text { per QALY } \\
\text { gained }\end{array}$} \\
\hline & $\begin{array}{l}\text { Once- } \\
\text { weekly } \\
\text { semaglutide } \\
1 \mathrm{mg}\end{array}$ & $\begin{array}{l}\text { Once-daily } \\
\text { liraglutide } \\
1.2 \mathrm{mg}\end{array}$ & Difference & $\begin{array}{l}\text { Once- } \\
\text { weekly } \\
\text { semaglutide } \\
1 \mathrm{mg}\end{array}$ & $\begin{array}{l}\text { Once-daily } \\
\text { liraglutide } \\
1.2 \mathrm{mg}\end{array}$ & Difference & \\
\hline $\begin{array}{l}\text { Treatment was } \\
\text { intensified with } \\
\text { insulin glargine }\end{array}$ & 6.58 & 6.28 & +0.30 & 26,211 & 26,365 & -155 & $\begin{array}{r}\text { Semaglutide } \\
\text { dominant }\end{array}$ \\
\hline $\begin{array}{l}\text { SGLT2 inhibitors } \\
\text { and sulfonylureas } \\
\text { discontinued at } \\
\text { treatment } \\
\text { intensification }\end{array}$ & 6.58 & 6.28 & +0.30 & 24,671 & 24,734 & -62 & $\begin{array}{r}\text { Semaglutide } \\
\text { dominant }\end{array}$ \\
\hline Deterministic analysis & 6.95 & 6.50 & +0.45 & 26,403 & 26,261 & +142 & 315 \\
\hline
\end{tabular}

$B M I$ body mass index, GBP 2018 pounds sterling, HbAIc glycated haemoglobin, ICER incremental cost-effectiveness ratio, QALY quality-adjusted life-year, SGLT2 sodium-glucose cotransporter 2, UKPDS United Kingdom Prospective Diabetes Study

\section{ACKNOWLEDGEMENTS}

Funding. Sponsorship for this study, the Rapid Service and Open Access Fees were funded by Novo Nordisk A/S. All authors had full access to all of the data in this study and take complete responsibility for the integrity of the data and accuracy of the data analysis.

Medical Writing Assistance. The authors are grateful to Helen Schofield and Caroline Freeman at Oxford PharmaGenesis for medical writing assistance (funded by Novo Nordisk $\mathrm{A} / \mathrm{S})$.

Authorship. All named authors meet the International Committee of Medical Journal Editors (ICMJE) criteria for authorship for this manuscript, take responsibility for the integrity of the work as a whole, and have given final approval to the version to be published.
Disclosures. Pierre Johansen and Barrie Chubb are employees and shareholders of Novo Nordisk A/S. Barnaby Hunt and Samuel J. P. Malkin are employees of Ossian Health Economics and Communications, which received consulting fees from Novo Nordisk A/S to support the preparation of the analysis. Anna Sandberg was an employee of Novo Nordisk A/S at the time of analysis and preparation of this manuscript. She is now a full-time employee of Oncopeptides. Matthew Capehorn is a partner at Clifton Medical Centre; is a partner and Clinical Manager of the Rotherham Institute for Obesity (RIO), which has received or is receiving research funding from Abbott, Bayer, BI/Lilly Alliance, Cambridge Weight Plan, GSK, Janssen, Leo Pharma, LighterLife, Merck, Novartis, Novo Nordisk and Syneos; is a Director of RIO Weight Management Limited; a Medical Director at LighterLife (paid position); is an unpaid board member of the Association for the Study for Obesity (ASO); has received honoraria for advisory board meetings for BI/Lilly Alliance, 
Janssen, MSK and Novo Nordisk; has received payments for speaker meetings from Abbott, BI/ Lilly Alliance, Novo Nordisk and Sanofi-Aventis; and has received travel and/or accommodation expenses to attend educational meetings from BI/Lilly, LighterLife and Novo Nordisk.

Compliance with Ethics Guidelines. This article is based on previously conducted studies and does not contain any studies with human participants or animals performed by any of the authors.

Data Availability. All data generated or analysed during this study are included in this published article.

Open Access. This article is licensed under a Creative Commons Attribution-NonCommercial 4.0 International License, which permits any non-commercial use, sharing, adaptation, distribution and reproduction in any medium or format, as long as you give appropriate credit to the original author(s) and the source, provide a link to the Creative Commons licence, and indicate if changes were made. The images or other third party material in this article are included in the article's Creative Commons licence, unless indicated otherwise in a credit line to the material. If material is not included in the article's Creative Commons licence and your intended use is not permitted by statutory regulation or exceeds the permitted use, you will need to obtain permission directly from the copyright holder.To view a copy of this licence, visit http://creativecommons.org/licenses/by$\mathrm{nc} / 4.0 /$.

\section{REFERENCES}

1. International Diabetes Foundation. IDF Diabetes Atlas, 9th edn. Brussels, Belgium: 2019. https:// www.diabetesatlas.org. Accessed December 2019.

2. Diabetes UK. Us, diabetes and a lot of facts and stats. 2019. https://www.diabetes.org.uk/resourcess3/2019-02/1362B_Facts\%20and\%20stats\% 20Update\%20Jan\%202019_LOW\%20RES_ EXTERNAL.pdf. Accessed February 2020.
3. International Diabetes Foundation. IDF Diabetes Atlas, 8th edn. Brussels, Belgium: International Diabetes Federation, 2017. United Kingdom Country report $2017 \& 2045$. https://reports.instantatlas. com/report/view/

704ee0e6475b4af885051bcec15f0e2c/GBR. Accessed October 2019.

4. Hex N, Bartlett C, Wright D, Taylor M, Varley D. Estimating the current and future costs of type 1 and type 2 diabetes in the UK, including direct health costs and indirect societal and productivity costs. Diabet Med. 2012;29(7):855-62.

5. National Institute for Health and Care Excellence. Type 2 diabetes in adults: management [NG28]. Updated August 2019. https://www.nice.org.uk/ guidance/ng28/chapter/1-

Recommendations\#blood-glucose-management-2. Accessed September 2019.

6. Tran KL, Park YI, Pandya S, et al. Overview of glucagon-like peptide-1 receptor agonists for the treatment of patients with type 2 diabetes. Am Health Drug Benefits. 2017;10(4):178-88.

7. Intensive blood-glucose control with sulphonylureas or insulin compared with conventional treatment and risk of complications in patients with type 2 diabetes (UKPDS 33). UK Prospective Diabetes Study (UKPDS) Group. Lancet. 1998;352(9131):837-53.

8. Advance Collaborative Group, Patel A, MacMahon $\mathrm{S}$, et al. Intensive blood glucose control and vascular outcomes in patients with type 2 diabetes. N Engl J Med. 2008;358(24):2560-72.

9. Holman RR, Paul SK, Bethel MA, Matthews DR, Neil HA. 10-year follow-up of intensive glucose control in type 2 diabetes. N Engl J Med. 2008;359(15): 1577-89.

10. NHS Digital. National Diabetes Audit, 2016-17. Care Processes and Treatment Targets short report 2017. https://files.digital.nhs.uk/publication/g/3/ national_diabetes_audit_2016-17_short_report_ care_processes_and_treatment_targets.pdf. Accessed September 2019.

11. European Medicines Agency. EPAR summary for the public. Ozempic 2018. https://www.ema.europa. eu/en/medicines/human/EPAR/ozempic. Accessed November 2019.

12. European Medicines Agency. EPAR summary for the public. Victoza 2017. https://www.ema.europa.eu/ en/documents/overview/victoza-epar-summarypublic_en.pdf. Accessed January 2020.

13. National Institute for Health and Care Excellence. Final appraisal determination. Liraglutide for the 
treatment of type 2 diabetes mellitus 2010. https:// www.nice.org.uk/guidance/ta203/documents/ diabetes-liraglutide-final-appraisal-determination3. Accessed January 2020.

14. Capehorn MS, Catarig AM, Furberg JK, et al. Efficacy and safety of once-weekly semaglutide $1.0 \mathrm{mg}$ vs once-daily liraglutide $1.2 \mathrm{mg}$ as add-on to $1-3$ oral antidiabetic drugs in subjects with type 2 diabetes (SUSTAIN 10). Diabetes Metab. 2019.

15. American Diabetes Association Consensus Panel. Guidelines for computer modeling of diabetes and its complications. Diabetes Care. 2004;27(9): 2262-5.

16. Bain SC, Hansen BB, Malkin SJP, et al. Oral semaglutide versus empagliflozin, sitagliptin and liraglutide in the UK: long-term cost-effectiveness analyses based on the PIONEER clinical trial programme. Diabetes Ther. 2020;11(1):259-77.

17. Viljoen A, Hoxer CS, Johansen P, Malkin S, Hunt B, Bain SC. Evaluation of the long-term cost-effectiveness of once-weekly semaglutide versus dulaglutide for treatment of type 2 diabetes mellitus in the UK. Diabetes Obes Metab. 2019;21(3): 611-21.

18. Gaede P, Johansen P, Tikkanen CK, Pollock RF, Hunt B, Malkin SJP. Management of patients with type 2 diabetes with once-weekly semaglutide versus dulaglutide, exenatide ER, liraglutide and lixisenatide: a cost-effectiveness analysis in the Danish setting. Diabetes Ther. 2019;10(4): 1297-317.

19. Pawaskar M, Bilir SP, Kowal S, Gonzalez C, Rajpathak S, Davies G. Cost-effectiveness of DPP-4 inhibitor and SGLT2 inhibitor combination therapy for type 2 diabetes. Am J Manag Care. 2019;25(5): 231-8.

20. Bilir SP, Hellmund R, Wehler E, Li H, Munakata J, Lamotte M. The cost-effectiveness of a flash glucose monitoring system for management of patients with type 2 diabetes receiving intensive insulin treatment in Sweden. Eur Endocrinol. 2018;14(2): 80-5.

21. Palmer AJ, Roze S, Valentine WJ, et al. The CORE diabetes model: projecting long-term clinical outcomes, costs and cost-effectiveness of interventions in diabetes mellitus (types 1 and 2) to support clinical and reimbursement decision-making. Curr Med Res Opin. 2004;20(Suppl 1):S5-26.

22. Palmer AJ, Roze S, Valentine WJ, et al. Validation of the CORE diabetes model against epidemiological and clinical studies. Curr Med Res Opin. 2004;20(Suppl 1):S27-40.
23. McEwan P, Foos V, Palmer JL, Lamotte M, Lloyd A, Grant D. Validation of the IMS CORE diabetes model. Value Health. 2014;17(6):714-24.

24. Mt Hood Diabetes Challenge Network. Economics, simulation modelling \& diabetes. https://www. mthooddiabeteschallenge.com/. Accessed March 2020 .

25. National Institute for Health and Care Excellence. Guide to the methods of technology appraisal 2013. https://www.nice.org.uk/process/pmg9/resources/ guide-to-the-methods-of-technology-appraisal2013-pdf-2007975843781. Accessed November 2019.

26. Clarke PM, Gray AM, Briggs A, et al. A model to estimate the lifetime health outcomes of patients with type 2 diabetes: the United Kingdom Prospective Diabetes Study (UKPDS) Outcomes Model (UKPDS no. 68). Diabetologia. 2004;47(10): 1747-59.

27. World Health Organization. Global Health Observatory data repository. https://apps.who.int/gho/ data/?theme $=$ main\&vid $=60000$. Accessed November 2019.

28. Davies MJ, D'Alessio DA, Fradkin J, et al. Management of hyperglycemia in type 2 diabetes, 2018 a consensus report by the american diabetes association (ADA) and the European Association for the study of diabetes (EASD). Diabetes Care. 2018;41(12):2669-701.

29. National Institute for Health and Care Excellence. Canagliflozin, dapagliflozin and empagliflozin monotherapy for treating type 2 diabetes. Assessment Report. Commercial in Confidence stripped version for consultation 2015. https://www.nice. org.uk/guidance/ta390/documents/assessmentreport. Accessed January 2020.

30. Willis M, Asseburg C, Nilsson A, Johnsson K, Kartman B. Multivariate prediction equations for HbA1c lowering, weight change, and hypoglycemic events associated with insulin rescue medication in type 2 diabetes mellitus: informing economic modeling. Value Health. 2017;20(3):357-71.

31. Frier BM, Jensen MM, Chubb BD. Hypoglycaemia in adults with insulin-treated diabetes in the UK: selfreported frequency and effects. Diabet Med. 2016;33(8):1125-32.

32. Curtis L, Burns A. Unit costs of health and social care 2018. Personal Social Services Research Unit, Kent 2019. https://www.pssru.ac.uk/project-pages/ unit-costs/unit-costs-2018/. Accessed November 2019. 
33. Beaudet A, Clegg J, Thuresson PO, Lloyd A, McEwan P. Review of utility values for economic modeling in type 2 diabetes. Value Health. 2014;17(4): 462-70.

34. Evans M, Khunti K, Mamdani M, et al. Health-related quality of life associated with daytime and nocturnal hypoglycaemic events: a time trade-off survey in five countries. Health Qual Life Outcomes. 2013;11:90.

35. Malkin SJP, Russel-Szymczyk M, Liidemann G, Volke V, Hunt B. Once-weekly semaglutide versus once-daily liraglutide for the treatment of type 2 diabetes: a long-term cost-effectiveness analysis in Estonia. Diabetes Ther. 2019;10(1):159-76.

36. Neslusan C, Teschemaker A, Willis M, Johansen P, Vo L. Cost-effectiveness analysis of canagliflozin $300 \mathrm{mg}$ versus dapagliflozin $10 \mathrm{mg}$ added to metformin in patients with type 2 diabetes in the United States. Diabetes Ther. 2018;9(2):565-81.

37. Gupta V, Willis M, Johansen P, et al. Long-term clinical benefits of canagliflozin $100 \mathrm{mg}$ versus sulfonylurea in patients with type 2 diabetes mellitus inadequately controlled with metformin in India. Value Health Reg Issues. 2019;18:65-73.

38. Marso SP, Bain SC, Consoli A, et al. Semaglutide and cardiovascular outcomes in patients with type 2 diabetes. $N$ Engl J Med. 2016;375(19): 1834-44.
39. Marso SP, Daniels GH, Brown-Frandsen K, et al. Liraglutide and cardiovascular outcomes in type 2 diabetes. N Engl J Med. 2016;375(4):311-22.

40. Evans M, Johansen P, Vrazic H, Pitcher AB, Falla E. The importance of incorporating cardio-protective effects of once-weekly semaglutide in estimates of health benefits for patients with type 2 diabetes. Diabetologia. 2018;61:427-8.

41. Lee AJ, Morgan CL, Morrissey M, Wittrup-Jensen $\mathrm{KU}$, Kennedy-Martin T, Currie CJ. Evaluation of the association between the EQ-5D (health-related utility) and body mass index (obesity) in hospitaltreated people with type 1 diabetes, type 2 diabetes and with no diagnosed diabetes. Diabet Med. 2005;22(11):1482-6.

42. Currie CJ, Morgan CL, Poole CD, Sharplin P, Lammert M, McEwan P. Multivariate models of healthrelated utility and the fear of hypoglycaemia in people with diabetes. Curr Med Res Opin. 2006;22(8):1523-34.

43. Viberti G, Kahn SE, Greene DA, et al. A diabetes outcome progression trial (ADOPT): an international multicenter study of the comparative efficacy of rosiglitazone, glyburide, and metformin in recently diagnosed type 2 diabetes. Diabetes Care. 2002;25(10):1737-43. 